\title{
ISOLATION AND IDENTIFICATION OF YEASTS AND FILAMENTOUS FUNGI FROM YOGHURTS IN BRAZIL
}

\author{
Silvia Regina Moreira ${ }^{1}$; Rosane Freitas Schwan ${ }^{1 *}$; Eliana Pinheiro de Carvalho $^{2}$; Alan E. Wheals ${ }^{1,3}$ \\ ${ }^{1}$ Departamento de Biologia and ${ }^{2}$ Ciência dos Alimentos, Universidade Federal de Lavras, Lavras, MG, Brazil. \\ ${ }^{3}$ Department of Biology and Biochemistry, University of Bath, Bath, UK
}

Submitted: March 01, 2001; Approved: April 27, 2001

\begin{abstract}
Seventy-two cartons of yoghurt were sampled three times at monthly intervals from four different local manufacturers. Total counts were close to $6 \times 10^{7}$ cells g $\mathrm{g}^{-1}$ of yoghurt. Yeast counts varied from 1 to 2,700 $\mathrm{g}^{-1}$. There was no evidence of systematic contamination at source but this longitudinal study revealed that $a d$ hoc contamination and improper storage led to the higher yeast counts. Contamination was generally higher in the hotter months but was lower overall than reported from other countries. A total of 577 yeast isolates were identified belonging to ten species. The most abundant yeasts were, in order, Debaryomyces hansenii, Saccharomyces cerevisiae, Mrakia frigida, Hansenula spp., Candida parapsilosis, Debaryomyces castellii and Candida maltosa. The psychrophilic yeast Mrakia frigida is reported for the first time in yoghurts. Low level contamination with Monilia and Penicillium species was found in a few samples. Growth tests suggested that ability to ferment sucrose, growth at $5^{\circ} \mathrm{C}$ and in the presence of $300 \mu \mathrm{g} \mathrm{g}^{-1}$ sorbate preservative, were the three most significant physiological properties to account for these yeasts in yoghurts. The data also suggest that warmer weather and inadequate refrigeration are the principal causes of higher levels of contamination, increased diversity and change in microbial flora.
\end{abstract}

Key words: yeasts, filamentous fungi, yoghurts, deterioration

\section{INTRODUCTION}

Fermentation is one of the classic methods to preserve foods. Milk can be fermented by bacteria, yeasts and filamentous fungi to produce a variety of products such as cheese, butter and yoghurt. Industrial production of yoghurt is a well-controlled fermentation process that includes the use of milk, sugar, fruit, flavouring, colouring, emulsifiers, and specific cultures of microorganisms to conduct the fermentation (22). The yoghurt base is essentially sterile since it is normally heated to about $90^{\circ} \mathrm{C}$ before inoculation with levels of lactic acid bacteria in excess of $10^{7} \mathrm{CFU} \mathrm{g} \mathrm{g}^{-1}$ to initiate the fermentation. In principle the microbiology of yoghurts is thus limited to essentially two bacterial species, Streptococcus salivarius subsp. thermophilus and Lactobacillus delbrueckii subsp. bulgaricus, often in a ratio of 2:1. All other micro-organisms present should be considered contaminants. Although bacteria can be spoilage organisms, yeasts and filamentous fungi are often involved in the deterioration of yoghurts $(8,9)$. They are responsible for offflavours, loss of texture quality due to gas production, and package swelling and shrinkage (12).

Ideally yoghurt should contain less than 10 yeast cells $\mathrm{g}^{-1}$ at the time of production and values higher than this will probably mean that the yoghurt will spoil before the normal (refrigerated) shelf life of 30 days. Usually fruit flavour and colour is added into yoghurt after fermentation. Contamination by yeasts is generally related to the fruits added and/or poor hygienic practices during packaging operation (9). The association of lactose-fermenting yeasts with dairy products is well established (28). Examples of yoghurts with more than $10^{6}$ cells $\mathrm{g}^{-1}$ have been recorded

\footnotetext{
* Corresponding author: Departamento de Biologia, Universidade Federal de Lavras, 37200-000, Lavras, MG, Brasil. Tel. (+5535) 829-1614; Fax (+5535) 829-1100. E-mail: rschwan@ufla.br
} 
$(10,13,23,27)$. In surveys of retail outlets in Portugal (27), Australia $(10,25)$ and Nigeria (13) it was reported that up to $60 \%$ of samples had counts in excess of $10^{4}$ cells $\mathrm{g}^{-1}$. Values of yeasts and moulds of between $10^{4}$ and $10^{5}$ cells g $^{-1}$ were reported in Egypt $(15,24)$. In the UK $(5,6)$ and Canada (2) up to $30 \%$ of samples had excess of $10^{3}$ cells g ${ }^{-1}$. Counts of more than $10^{2}$ cell g$^{-1}$ were reported in $95 \%$ of yoghurts in Spain (3). In the USA $(14,20)$ and the Netherlands (18) contamination was slightly less.

Yoghurt consumption in Brazil has increased about ten-fold during the last decade although it is still behind that of developed countries. Data in a recent study (17) suggested that mould and yeast contamination of Brazilian yoghurts was generally very low with 11 out of 17 samples containing 10 or less (unidentified) fungi or yeasts per gram and only two with high levels $\left(10^{4}-10^{5}\right.$ cells $\mathrm{g}^{-1}$ ). This suggested that improved hygiene precautions were now being adopted. The present study was undertaken with the aim of extending these quantitative data on incidence in both standard and fruit yoghurts, examining contamination in the same products over a period of time, identifying the contaminating yeasts and moulds, and attempting to characterise some of the physiological factors for their growth in yoghurts. Preliminary work revealed that two international-brand manufacturers had the best possible standards and yeast counts were always below 10 cells $\mathrm{g}^{-1}$ (data not shown). Accordingly, effort was put into analysing smaller-scale, local manufacturers where it was considered, a priori, that hygiene conditions might not be of the highest standard.

\section{MATERIALS AND METHODS}

\section{Sampling}

Yoghurt samples in $200 \mathrm{ml}$ plastic containers were purchased in the months of April, May and June 1997. Six different brands/ types were studied including both plain and fruit yoghurts from four different local manufacturers using different sources of milk. Each brand/type was obtained from four different supermarkets in the South of Minas Gerais, Brazil providing 72 samples in total. All samples were transported in an ice-box to the laboratory, where they were processed immediately. Guided by date coding, only samples that were within five days of manufacture were chosen for chemical and microbiological analysis.

\section{Isolation and enumeration of yeasts and moulds}

The contents of each yoghurt container were uniformly mixed, and a $10.0 \mathrm{ml}$ sample was aseptically withdrawn, mixed in a flask containing $90 \mathrm{ml}$ of $0.1 \%$ of sterile peptone solution, and then diluted for counting purposes. The total microbial population was determined by using Plate Count Agar (PCA; 16). Inoculated plates were incubated at $28^{\circ} \mathrm{C}$ for 48 hours. Filamentous fungi and yeasts were enumerated on acidified YEPG agar (yeast extract 10g; peptone $20 \mathrm{~g}$; glucose $20 \mathrm{~g}$; agar $15 \mathrm{~g} \mathrm{~L}^{-1}$ ) which had been adjusted to $\mathrm{pH} 3.5$ by the addition of sterilised $1 \mathrm{~N}$ HCL after being autoclaved. Five $\mathrm{ml}$ of yoghurt was incorporated into the medium to ensure it was suitable for the indigenous species, and the inoculated plates were incubated at $29^{\circ} \mathrm{C}$ for 7 days. The acidity was sufficient to suppress bacterial growth. Filamentous fungi and yeasts were isolated from acidified YEPG and checked for purity with only one isolate being contaminated with bacteria. The strains were then cultured onto YEPG plates and maintained on YM (yeast extract 3.0g, malt extract $3.0 \mathrm{~g}$, peptone $5.0 \mathrm{~g}$, glucose $10 \mathrm{~g}$, agar $15 \mathrm{~g}$ per litre of water) slants (29). The four-fold replication revealed a range of counts within $2 \%$ of the mean. Only mean values are shown in the tables.

\section{Yeast identification and characteristics}

Isolates were sampled according to FDA criteria (11) and were identified to species level by physiological and morphological standard methods as recommended by Kreger van Rij (19) and Kurtzman and Fell (21). A total of 75 tests were done: Assimilation of glucose, galactose, L-sorbose, sucrose, maltose, cellobiose, trehalose, lactose, melibiose, raffinose, melezitose, inulin, soluble amides, D-xylose, L- and D-arabinose, D-ribose, L-rhamnose, Dglucosamine, N-acetyl-D-glucosamine, methanol, ethanol, glycerol, erythritol, ribitol, galactitol (dulcitol), D-mannitol, Dsorbitol, $\propto$-methyl-D-glucoside, salicin, D-gluconic acid, DL-lactic acid, sodium succinate, sodium citrate, inositol, hexadecane, $\propto$-ketoglutaric acid, xylitol, L-arabinitol, propane 1.2 diol, butane 2.3 diol, lysine, ethylamine, potassium nitrate, cadaverine, creatine and glucosamine. The other tests were fermentation of glucose, sucrose, maltose, galactose, raffinose, lactose, trehalose, melezitose, cellobiose and inulin, starch formation, growth on presence of cycloheximide $(1 \%, 0.1 \%$ and $0.01 \%)$, growth on media containing $50 \%$ of glucose, growth at different temperatures $\left(40^{\circ} \mathrm{C}\right.$, $37^{\circ} \mathrm{C}, 34^{\circ} \mathrm{C}, 25^{\circ} \mathrm{C}, 19^{\circ} \mathrm{C}, 17^{\circ} \mathrm{C}$ ), growth on vitamin-free medium, growth on $10 \% \mathrm{NaCl}$ with $5 \%$ glucose, production of a true mycelium, production of pseudo-mycelium, vegetative reproduction by budding or splitting, production of ascospores, production of basidiospores and growth on $5 \%$ malt extract (scoring cell and colony shape).

All species names are from Kurtzman and Fell (21) except for the genus Hansenula. This genus name has been retained since some isolates were identified before the publication of Kurtzman and Fell (21) when the proposal to disband this genus was incorporated in this definitive yeast taxonomic text with the different species being placed in the genera Pichia, Williopsis and Debaryomyces.

Growth at $5^{\circ} \mathrm{C}$ and $10^{\circ} \mathrm{C}$ was measured by inoculation of all identified isolates onto YEPG plates and incubation for 7 days. Resistance to sorbate and benzoate preservatives was determined by culturing the isolates on malt extract agar (malt extract $3 \% \mathrm{w} / \mathrm{v}$, peptone $0.5 \% \mathrm{w} / \mathrm{v}$, agar $1.5 \% \mathrm{w} / \mathrm{v}$ ) that incorporated either potassium sorbate or sodium benzoate per ml. Sorbate and benzoate were filter sterilised and added to the medium adjusted to $\mathrm{pH} 4$ with $1 \mathrm{~N} \mathrm{HCL}$. Plates were incubated for 5 days at $25^{\circ} \mathrm{C}$. Four replicates were done for each isolate. 


\section{Filamentous fungi identification}

Fungal isolates were identified by colony and cell morphology and microscopical observation of conidiospore formation (1).

\section{RESULTS AND DISCUSSION}

\section{Microorganism counts}

Four samples were taken of each type of yoghurt and they showed a range in viable count of $\pm 2 \%$ (data not shown). This indicates that there was no systematic problem in either storage or handling of the yoghurts in any of the retail outlets from which the yoghurts were purchased. The mean values (Table 1) show there was also no obvious association between time of sampling (batch number) and total count. All manufacturers inoculated lactic acid bacteria above the required density of about $10^{7}$ cells $\mathrm{g}^{-1}$ but total counts showed a seven-fold range from $1.2 \times 10^{7}$ to $8.8 \times 10^{7} \mathrm{CFU}$ $\mathrm{g}^{-1}$. Two manufacturers (A and C) had substantially higher counts suggesting poorer control of their production process. Yeast counts varied from one to $2,723 \mathrm{CFU} \mathrm{g}^{-1}$ and the highest counts were associated with the same two manufacturers suggesting poorer standards of hygiene at these factories. There was a clear association between levels of yeast contamination and time of year. Yeast cell density was approximately one order of magnitude higher in April than in June in five out of six brands/types. The reason for this could be the ambient temperature that was $28^{\circ} \mathrm{C}$ to $32^{\circ} \mathrm{C}$ in April (autumn) and $18^{\circ} \mathrm{C}$ to $22^{\circ} \mathrm{C}$ in June (winter). There was no association between presence and absence of flavouring and level of yeasts even when the two types were from the same manufacturer. Many of the yoghurts were at the best possible specification of less than 10 cells per gram and overall the level of contamination was much lower than reported in other countries.

\section{Yeast species}

A total of 577 yeast isolates were identified to species level from 72 yoghurt samples (Table 2). The ten species were, with numbers identified in parentheses, Debaryomyces hansenii (191), Saccharomyces cerevisiae (114), Hansenula spp. (91), Mrakia frigida (68), Candida parapsilosis (44), Debaryomyces castellii (33), Candida maltosa (31), Schizosaccharomyces pombe (3),
Candida mogii (1) and Kluyveromyces marxianus (1). All, except M. frigida (formerly Leucosporidium gelidum), have been found before in yoghurts. The identification similarity index for M. frigida was $95.5 \%$ whereas the next candidate species, Debaryomyces ranrijii, was only $80 \%$ similar. The psychrophilic yeast Mrakia frigida has been found before in frozen foods and cold-stored orange juice (7) demonstrating that it can cope well with the acidic, high sugar environments of both yoghurts and fruit juice. There was no association between total yeast count and number of species found but the diversity was twice as great in batches one and two (an average of three species per lot) compared to batch three. Perhaps this reflects the ability of more yeasts to grow when the yoghurts were improperly stored in the warmer autumn months. In principal, increased diversity could lead to increased mutualism in breaking down and utilising the food substrate and thus enhancing spoilage. Different species of yeasts were found from the same manufacturer on different occasions suggesting that there was not systematic infection at source but ad hoc infection and then propagation of that species. Only M. frigida was found in all three batches and only $D$. hansenii was found in at least one sample from all manufacturers. $D$. hansenii was also the most abundant species, found in 11 out of 18 samples yet was not found in June whereas S. cerevisiae was only found in June in yoghurts from three manufacturers. $D$. hansenii was the most frequently isolated yeast in yoghurt samples from Australia and the United Kingdom $(9,25,26)$.

The batches with and without fruit flavouring from manufacturer $\mathrm{E} / \mathrm{F}$ were likely to have been produced as one lot with fruit added to some of the batch. This is consistent with the range of species found, the consistently low yeast counts and the drop in $\mathrm{pH}$ by about 0.2 units on addition of the strawberry fruit. By contrast, the batches with and without fruit flavouring from manufacturer $\mathrm{A} / \mathrm{B}$ were apparently made separately as indicated by the range of species, the difference in counts and the lack of congruency between the $\mathrm{pH}$.

\section{Physiological characterization}

Some basic physiological characterization of all the yeasts was performed in order to determine their ability to grow under

Table 1. Total count of micro-organisms in six brands/types of yoghurts collected in three monthly batches.

\begin{tabular}{|c|c|c|c|c|c|c|c|c|c|}
\hline \multicolumn{4}{|c|}{$\mathrm{Batch}^{1} 1$} & \multicolumn{3}{|c|}{ Batch 2 } & \multicolumn{3}{|c|}{ Batch 3} \\
\hline Lot $^{2}$ & Flavouring & Total count & Yeast count & Lot & Total count & Yeast count & Lot & Total count & Yeast count \\
\hline A1 & No & $3.7 \times 10^{7}$ & 790.25 & A2 & $8.8 \times 10^{7}$ & 214.00 & A3 & $3.0 \times 10^{7}$ & 89.92 \\
\hline B1 & Yes & $1.9 \times 10^{7}$ & 10.37 & B2 & $4.6 \times 10^{7}$ & 1.20 & B3 & $4.4 \times 10^{7}$ & 1.62 \\
\hline $\mathrm{C} 1$ & Yes & $5.5 \times 10^{7}$ & 2723.00 & $\mathrm{C} 2$ & $8.6 \times 10^{7}$ & 289.25 & $\mathrm{C} 3$ & $8.6 \times 10^{7}$ & 142.75 \\
\hline D1 & Yes & $6.5 \times 10^{7}$ & 13.72 & D2 & $2.2 \times 10^{7}$ & 1.65 & D3 & $2.0 \times 10^{7}$ & 12.90 \\
\hline E1 & No & $1.8 \times 10^{7}$ & 43.95 & E2 & $1.2 \times 10^{7}$ & 2.60 & E3 & $1.4 \times 10^{7}$ & 1.00 \\
\hline F1 & Yes & $4.3 \times 10^{7}$ & 10.40 & $\mathrm{~F} 2$ & $2.9 \times 10^{7}$ & 1.52 & F3 & $1.3 \times 10^{7}$ & 1.27 \\
\hline
\end{tabular}

${ }^{1}$ The numbers 1, 2 and 3 refer to batches in April, May and June 1997 respectively; ${ }^{2}$ The lot code refers to the type/brand of yoghurt.

The four manufacturers are designated A/B, C, D and E/F. Counts are in colony forming units (CFU) $\mathrm{g}^{-1}$ of yoghurt. 
Table 2. Yeast diversity found in yoghurts sampled from three different batches

\begin{tabular}{|c|c|c|c|c|}
\hline \multicolumn{2}{|c|}{ Yoghurts } & \multicolumn{3}{|c|}{ Batch number $^{1}$} \\
\hline $\operatorname{Lot}^{2}$ & Flavouring & 1 & 2 & 3 \\
\hline A & No & $\begin{array}{l}\text { Mrakia frigida (20), Candida maltosa } \\
\text { (12), Candida parapsilosis (5), } \\
\text { Schizosaccharomyces pombe (2), } \\
\text { Candida mogii (1), Kluyveromyces } \\
\text { marxianus (1) }\end{array}$ & $\begin{array}{l}\text { Mrakia frigida }(12), \\
\text { Debaryomyces hansenii }(7), \\
\text { Candida parapsilosis }(2), \\
\text { Schizosaccharomyces pombe (1) }\end{array}$ & Hansenula spp. (36) \\
\hline B & Yes & $\begin{array}{l}\text { Debaryomyces hansenii (18), Candida } \\
\text { parapsilosis (8), Candida maltosa (4) }\end{array}$ & $\begin{array}{l}\text { Debaryomyces hansenii (19), } \\
\text { Debaryomyces castellii (9) }\end{array}$ & $\begin{array}{l}\text { Hansenula spp (26), } \\
\text { Mrakia frigida (12) }\end{array}$ \\
\hline $\mathrm{C}$ & Yes & $\begin{array}{l}\text { Candida parapsilosis }(18), \\
\text { Debaryomyces hansenii (12), Candida } \\
\text { maltosa (10) }\end{array}$ & $\begin{array}{l}\text { Debaryomyces hansenii (18), } \\
\text { Mrakia frigida (8) }\end{array}$ & $\begin{array}{l}\text { Saccharomyces cerevisiae } \\
\text { (35), Mrakia frigida (8), } \\
\text { Hansenula spp.(5) }\end{array}$ \\
\hline $\mathrm{D}$ & Yes & Debaryomyces hansenii (32) & $\begin{array}{l}\text { Debaryomyces hansenii (16), } \\
\text { Debaryomyces castellii (12) }\end{array}$ & $\begin{array}{l}\text { Saccharomyces cerevisiae } \\
(44)\end{array}$ \\
\hline $\mathrm{E}$ & No & $\begin{array}{l}\text { Debaryomyces hansenii (10), Mrakia } \\
\text { frigida (8), Candida maltosa (5) }\end{array}$ & $\begin{array}{l}\text { Debaryomyces hansenii ( } 31) \text {; } \\
\text { Debaryomyces castellii ( } 8)\end{array}$ & $\begin{array}{l}\text { Saccharomyces cerevisiae } \\
\text { (17) }\end{array}$ \\
\hline $\mathrm{F}$ & Yes & $\begin{array}{l}\text { Debaryomyces hansenii (20), Candida } \\
\text { parapsilosis (11) }\end{array}$ & $\begin{array}{l}\text { Hansenula spp. }(24) \text {, } \\
\text { Debaryomyces hansenii ( } 8) \text {, } \\
\text { Debaryomyces castellii (4) }\end{array}$ & $\begin{array}{l}\text { Saccharomyces cerevisiae } \\
(18)\end{array}$ \\
\hline
\end{tabular}

${ }^{1}$ The numbers 1, 2 and 3 refer to batches in April, May and June 1997 respectively; ${ }^{2}$ The lot code refers to the type/brand of yoghurt. The four manufacturers are designated A/B, C, D and E/F. Numbers in parentheses are the number of isolates identified as that species.

Table 3. Physiology of yeast species found in yoghurts.

\begin{tabular}{lccccccccc}
\hline \multirow{2}{*}{ Yeast species } & \multicolumn{2}{c}{ Growth at } & \multicolumn{2}{c}{ Fermentation of } & Growth on sorbate at & \multicolumn{2}{c}{ Growth on benzoate at } \\
\cline { 2 - 9 } & $5^{\circ} \mathrm{C}$ & $10^{\circ} \mathrm{C}$ & Sucrose & Lactose & $150 \mu \mathrm{gl}^{-1}$ & $300 \mu \mathrm{g} \mathrm{ml}^{-1}$ & $150 \mu \mathrm{g} \mathrm{ml} \mathrm{g}^{-1}$ & $300 \mu \mathrm{g} \mathrm{ml}$ \\
\hline Debaryomyces hansenii & + & + & + & - & + & + & + & + \\
Saccharomyces cerevisiae & $\mathrm{W}$ & + & + & - & + & - & + & + \\
Mrakia frigida & + & + & + & - & + & + & + & + \\
Candida parapsilosis & $\mathrm{W}$ & + & $\mathrm{W}$ & - & + & $\mathrm{W}$ & $\mathrm{W}$ & $\mathrm{W}$ \\
Candida maltosa & $\mathrm{W}$ & + & + & - & + & - & + & - \\
Debaryomyces castellii & + & + & + & - & + & $\mathrm{W}$ & + & $\mathrm{W}$ \\
Schizosaccharomyces pombe & $\mathrm{W}$ & + & + & - & + & + & + & $\mathrm{W}$ \\
Candida mogii & + & + & + & - & + & $\mathrm{W}$ & + & $\mathrm{W}$ \\
Kluyveromyces marxianus & $\mathrm{W}$ & + & + & + & + & + & + & + \\
\hline
\end{tabular}

$+=$ positive, - = negative, $\mathrm{W}=$ weak or slow growth.

the selective conditions found in yoghurt (Table 3). All yeast species identified were able to ferment sugars but, despite yoghurt containing significant amounts of lactose, only a single isolate of a lactose-fermenting species, $K$. marxianus, was found. All other (glucose-fermenting) yeasts were abundant in both standard (plain) and fruit (glucose-rich) yoghurts. Species of Debaryomyces and Kluyveromyces were also able to assimilate lactose suggesting that yoghurt is a particularly good substrate for their growth. The presence of lactose non-fermenting yeasts in yoghurts might be explained by the higher concentration of sucrose added to this product. All the species isolated were able to grow at $10^{\circ} \mathrm{C}$ and many grew well at $5^{\circ} \mathrm{C}$, a temperature close to the $4^{\circ} \mathrm{C}$ found in even well refrigerated conditions. $K$. marxianus cells inoculated into yoghurts were able to grow from $10^{2}$ to $10^{6} \mathrm{CFU} \mathrm{ml}{ }^{-1}$ during 30 days of storage at $4^{\circ} \mathrm{C}$ (4). Sorbate is an approved preservative for yoghurt and benzoate is an approved preservatives for fruits and both are added in Brazil at up to $300 \mu \mathrm{g} \mathrm{g}^{-1}$. Most of the yeasts could grow (albeit weakly) 
at the higher concentrations. It has been concluded (10) that the most important determinants in relation to yeast contamination of yoghurt seem to be (i) ability to grow well at low temperatures, (ii) ability to ferment sucrose and/or lactose, (iii) production of enzymes to hydrolyse milk fat and proteins and (iv) assimilation of lactic and citric acids. Of the factors tested here, lactose fermentation was clearly not a major determinant. D. hansenii, the most common contaminant both in Brazil and elsewhere, had attributes (i) and (ii) and was also resistant to the added preservatives, a factor that looks to be important. Its "physiological profile" in Table 2 was only matched by $M$. frigida suggesting the reason for its abundance. S. cerevisiae is an exception to this pattern probably because it has the ability to outgrow almost any other yeast when given sucrose as a substrate.

\section{Filamentous fungi identification}

Filamentous fungi were found at low levels only in two lots of fruit pulp yoghurts from one batch. Batch B1 had $21 \mathrm{CFU} \mathrm{g}^{-1}$ of Monilia and 4 CFU g ${ }^{-1}$ of Penicillium and batch $\mathrm{C} 1$ had 6 CFU $\mathrm{g}^{-1}$ of Monilia suggesting that systematic infection was not occurring and growth conditions for the fungi were unfavourable.

\section{CONCLUSIONS}

The last major survey showed an unacceptably high level of yeast contamination in yoghurts in many countries (8). The most important conclusion in this study is the overall high quality of the hygiene in the preparation of yoghurts. Of the eight lots of yoghurt analysed (including the unpublished data from the international manufacturers) only two, from two different local manufacturers, showed unacceptably high levels of yeasts. The other six lots were at, or close to, the best possible international standards. Since these results were from local manufacturers in a developing country, it strongly suggests that there has been global and systematic improvement of hygiene standards since the analyses of less than a decade ago.

It is already known that psychrophiles are potentially major food spoilage organisms of refrigerated foods and beverages. The first discovery of widespread incidence of Mrakia frigida suggests that other cold tolerant, acid-loving yeasts are likely to emerge as contaminants in the future. It emphasises once again the need for good manufacturing practice.

This longitudinal study with repeated sampling from the same producer gave additional information on how the contaminating flora changes with time. Provided the producer has good hygienic practices, the flora is not primarily a function of producer but time of manufacture. The data suggest that warmer weather and inadequate refrigeration are the principal causes of higher levels of contamination, increased species diversity and change in microbial flora.

\section{ACKNOWLEDGEMENTS}

SRM had scholarships from CAPES and CNPq and AEW was supported by FAPEMIG (CAG 81/98).

\section{RESUMO}

\section{Isolamento e identificação de leveduras e fungos filamentosos em iogurtes}

Setenta e duas embalagens de iogurtes de quatro indústrias diferentes foram analisadas durante três épocas diferentes com intervalo mensal. A população microbiana total encontrada foi em torno de $6 \times 10^{7}$ células $\mathrm{g}^{-1}$ de iogurte. A contagem de leveduras variou entre 1 a 2.700 células $g^{-1}$. Não foi possível observar uma sistemática contaminação, mas este estudo longitudinal revelou que contaminação ad hoc e armazenamento impróprio pode levar a elevadas populações de leveduras. De modo geral foi detectada uma contaminação maior nos meses mais quentes do ano mas em valores inferiores aos encontrados em outros países. Um total de 577 isolados de leveduras foram identificados como pertencentes a 10 espécies. As leveduras mais abundantes foram, em ordem, Debaryomyces hansenii, Saccharomyces cerevisiae, Mrakia frigida, Hansenula spp., Candida parapsilosis, Debaryomyces castellii e Candida maltosa. A levedura psicrófila, Mrakia frigida foi pela primeira vez mencionada como isolada a partir de iogurtes. Foi encontrada em algumas amostras uma pequena contaminação por espécies de Monilia e Penicillium. Os testes utilizados para crescimento sugeriram que habilidade para fermentar sacarose, crescimento a $5^{\circ} \mathrm{C}$ e na presença de $300 \mu \mathrm{g} \mathrm{g}^{-1}$ de sorbato foram as três propriedades fisiológicas mais importantes para a presença destas leveduras em iogurtes. Os dados também sugerem que clima mais quente e refrigeração inadequada são as principais causas de alta nível de contaminação, aumento da diversidade e mudança na microbiota presente.

Palavras-chave: leveduras, fungos filamentosos, iogurtes, deterioração

\section{REFERENCES}

1. Alexopoulos, C.J.; Mims, C.W.; Blackwell, M. Introductory Mycology, $4^{\text {th }}$ ed. John Wiley, New York, 1996, 869pp

2. Arnott, D.R.; Duitschaever, C.L.; Bullock, D.H. Microbiological evaluation of yogurt produced commercially in Ontario. J. Milk Food Technol., 37:11-13, 1974.

3. Brazal-García, T.; Ruiz, L.R-A.; Díaz, M.E. Microbiología sanitaria de los yogures, naturales y com sabores, de consumo en la provincia de Alicante. Alimentaria, 177:39-42, 1986

4. Canganella, F.; Ovidi, M.; Paganini, S.; Vettraino, A.M.; Bevilacqua, L.; Trovatelli, L.D. Survival of undesirable micro-organisms in fruit yoghurts during storage at different temperatures. Food Microbiol., 15:71-77, 1998

5. Davis, J.G. Yogurt in the United Kingdom: chemical and microbiological analysis. Dairy Indust., 39:149-157, 1974. 
6. Davis, J.G. The microbiology of yogurt, In: J.G. Carr; C.V.; Cutting; G.C. Whiting (eds.), Lactic acid bacteria in beverages and food, Academic press, London, 1975, pp. 245-266.

7. Fell, J.W.; Statzell-Tallman, A. Mrakia. In The yeasts: A taxonomic study (4th ed) (Eds Kurtzman, C.P.: Fell, J.W.), 1988, pp. 676-677. Elsevier Press, Amsterdam.

8. Fleet, G. Spoilage yeasts. Crit. Rev. Biotechnol., 12:1-44, 1992.

9. Fleet, G. Yeasts in dairy products, J. Appl. Bacteriol., 68:199-211, 1990.

10. Fleet, G.H.; Mian, M.A. The occurrence and growth of yeasts in dairy products. Int. J. Food Microbiol., 1987, 4:145-155.

11. Food and Drug Administration. Bacteriological Analysis Manual ( $8^{\text {th }}$ ed) AOAC International, Gaithersburg, Md, USA, 1995, pp566.

12. Foschino R.; Garzarolli, C.; Ottogli, G. Microbial contaminants cause swelling and inward collapse of yoghurt packs. Lait, 73:395-400, 1993.

13. Green, M.D.; Ibe, S.N. Yeasts as primary contaminants in yogurts produced commercially in Lagos, Nigeria. J. Food Protect., 1987, 50:193-198.

14. Hankin, L.; Shields, D. Quality of yogurt. Bulletin 785 of the Connecticut Agricultural Experimental Station, Connecticut Agricultural Experimental Station, New Haven, 1980, pp1-11.

15. Haridy, M.S.A. Occurrence of yeasts in yogurt, cheese and whey. Cryptogamie Mycologie, 1993, 14:255-262.

16. Harrigan, W.F.; McCance, M.E. Laboratory methods in food and dairy microbiology, Academic Press, London, 1976, 353 pp.

17. Hoffmann, F.L.; Pagnocca, F.C.; Fazio, M.L.S.; Vinturim, T.M. Iogurte: Falta de cuidados altera qualidade microbiológica. Indústria de laticínios, 1996, 1:32-34.
18. Hup, G.; Stadhoulders, J. Comparison of media for the enumeration of yeasts and moulds in dairy products. Netherlands Milk Dairy J., 1972, 26:131-140.

19. Kreger-Van-Rij, N.J.W. The Yeasts: A Taxonomic Study ( $3^{\text {rd }}$ ed), Elsevier, Amsterdam, 1984, $1082 \mathrm{pp}$.

20. Kroger, M. Quality of yogurt, J. Dairy Sci., 1976, 59:344-350.

21. Kurtzman, C.P.; Fell, J.W. (Eds.) The Yeasts, A taxonomic study $\left(4^{\text {th }}\right.$ ed), Elsevier Press, Amsterdam, 1998, pp.1055.

22. Robinson, R.K.; Tamime, A.Y. (1975) Yogurt - a review of the product and its manufacture. J. Soc. Dairy Technol., 1975, 28:149-163.

23. Rohm, H.; Lechner, F.; Lehner, M. Microflora of Austrian natural-set yogurt. J. Food Protect., 53:478-480, 1990.

24. Saad, N.M.; Moustafa, M.K.; Ahmed, A.A.H. Microbiological quality of yoghurt produced in Assiut City. Assiut Vet. J., 1987, 19:87-91

25. Suriyarachchi, V.R.; Fleet, G.H. Occurrence and growth of yeasts in yogurts. Appl. Environm. Microbiol., 1981, 42:574-579.

26. Tilbury, R.H.; Davis, J.G.; French, E.K.; Imrie, K.; Campbell-Lent, K.; Orbell, C. Taxonomy of yeasts in yogurts and other dairy products. In: Fourth International Symposium on Yeasts. Klaushofer, H.; Sleyter, V.B. (Eds.), 1974, pp. 265-266. Vienna, Hochschulerschaft an der Hochschule für Bodenkultur.

27. Van-Uden; N.; Carmo-Sousa, I.D. Presumptive tests with liquid media for coliform organisms in yogurt in the presence of lactose fermenting yeasts. Dairy Industries, 22:1029-1029, 1957.

28. Walker, H.W.; Ayres, J.C. Yeasts as spoilage organisms, In The yeasts, volume 3, yeast technology. Rose, A.H.; Harrison, J.S. (Eds.), 1970, pp. 464-527. Academic Press, London.

29. Wickerham, L.J. Taxonomy of Yeasts: I - Technique of Classification, (Technical Bulletin, 1029), U.S. Department of Agriculture, Washington: D. C., 1951, pp. 1-56. 